\title{
THE ESTONIAN LANGUAGE AS PRESENTED IN THE GREAT SOVIET ENCYCLOPAEDIA: LANGUAGE DESCRIPTIONS AND IDEOLOGY ${ }^{1}$
}

\author{
Ekaterina Velmezova
}

\begin{abstract}
Articles about the Estonian language published in the three editions of the Great Soviet Encyclopaedia bear the imprint of their epochs and ideologies. It becomes apparent even in the fragments of articles that contain language description 'as such' and should have been the most neutral ones. The article about Estonian from the first edition of the encyclopaedia seems the most ideologically marked: the view of Estonian in the general social context evidently prevails, while the language itself is only described to a lesser degree. This can be explained by political and social reasons.
\end{abstract}

Keywords: Estonian language, Great Soviet Encyclopaedia, linguistics and ideology, linguistic theories

At first sight, it may seem that articles about languages published in universal dictionaries and encyclopaedias should be extremely concise and impartial. ${ }^{2}$ However, it turns out that these language descriptions are ideologically marked, to a greater or lesser extent; ${ }^{3}$ for instance, they can reflect particular views of human language in general, which prevailed in the epochs and countries in which they appeared. This article demonstrates it on the example of articles about the Estonian language published in three editions of the Great Soviet Encyclopaedia.

The Great Soviet Encyclopaedia (hereinafter the GSE) earned itself the reputation of the most complete and well-known universal Soviet encyclopaedia. It was published in three editions: the first one (1926-1947) consisted of 66 volumes, ${ }^{4}$ the second one (1949-1958) of 52 volumes, ${ }^{5}$ and the third one (1969-1981) of 31 volumes. ${ }^{6}$

Articles titled "The Estonian Language" and published in these three editions (D. B. \& K. B. 1934, nomen nominandum 1957b, and Ageeva 1978, correspondingly) differ from each other considerably, which could already be seen on the example of their authorship. In the GSE third edition the author's name is provided: the article was written by Ruf' Aleksandrovna Ageeva (born 1938); 
in the second edition the article was published without any indication of its authorship under the text of the article; as to the first edition, the initials D. B. most probably refer to the name of Dmitrii Bubrikh (1890-1949), one of the most prominent Soviet scholars specialising in Finno-Ugric studies.

The volume of these three articles also varies from one text to another. The first one contains only 37 lines, the second (the most detailed one) - 99 lines, and the third, the most laconic one - 34 lines.

The articles are also very different as to their content and the manner in which they present the Estonian language: it is the article from the first edition that seems the most peculiar, considering all the parameters. ${ }^{7}$

\section{FROM 'LINGUISTICS AS SUCH' (?) ...}

\section{Estonian dialects and native speakers}

In the article from the GSE first edition, Estonian is described irrespectively of its native speakers: "Estonian language (eesti keel) belongs to the Ugro-Finnic language system" (D. B. \& K. B. 1934: 720) (about the notion of system in this context see below). On the contrary, in the GSE second and third editions, Estonian is defined, first of all, as a language of particular (native) speakers; here it is evidently presupposed that (the) language is first of all a means of communication. Besides, at the time when the second and third editions were published, Estonia was already a part of the USSR; ${ }^{8}$ therefore it made sense to speak about the native speakers of Estonian in connection with the topic of the "Soviet population" in general. ${ }^{9}$ In the GSE second edition, the Estonian language is defined simply as the language of Estonians (nomen nominandum 1957b: 225), while in the article from the third edition we find some more detailed information: it is the "language of Estonians living in the Estonian Soviet Socialist Republic, in the Leningrad, Pskov, and Omsk oblasts and in other regions of the Russian Soviet Federative Socialist Republic, in the Latvian and Ukrainian Soviet Socialist Republics, in the Abkhaz Autonomous Soviet Socialist Republic, and also in Sweden, USA, and Canada. The total number of speakers in the USSR is 1007,4 thousands [sic] of people (1970, [general] census)"(Ageeva 1978) ${ }^{10}$ (information about the total number of Estonian speakers was also absent in the articles from the two first editions of the GSE; the question of the geographical spread of Estonian was not raised there either).

As to the main Estonian dialects, they are discussed in all three articles, but each time a particular dialectal division of Estonian is proposed. In the article from the first edition, two dialects [narechie] are mentioned: "The Es- 
tonian language [...] is divided into two dialects that differ considerably from one another: the northern, or the Revel one, and the southern, or the Dorpat one" (D. B. \& K. B. 1934: 720). In the article from the GSE third edition, three dialects are discussed:

The Estonian language [...] has three basic dialects: the north-eastern coastal, the north-Estonian and the south-Estonian ones. Beginning in the 16th century, there existed [in Estonian] two literary languages on the basis of the north-Estonian and the south-Estonian dialects. (Ageeva 1978)

The article from the GSE second edition represents some kind of intermediary version between the articles from the first and the third editions. Like in the article from the third edition, three dialects [narechie] are mentioned here, but as the basic dialectal opposition in this article is also mentioned that of the 'north' and 'south', supposing the binary dialectal division of Estonian:

The Estonian language [...] is divided into three dialects [narechie]: the northern, the north-eastern and the southern ones, which, in their turn, are divided into dialects [dialekt] and patois [govor]. The south-Estonian dialect, the basis of which was constituted by an ancient independent Baltic-Finnic language, is manifestly different from the two others, going back to another ancient language. The middle northern dialect [srednii dialekt severnogo narechiia] was chosen as the basis of the national literary Estonian language. Before the early 20th century, books were also printed in the south-Estonian dialect. At present, dialects tend to disappear. (Nomen nominandum 1957b: 226)

Different interpretations are obviously given here to a similar situation, and this allows us once again to raise the question about the objectivity in language descriptions - even in those that seem the most neutral.

\section{About the Estonian written language}

From the GSE first edition we learn that "the Estonian written language (using Roman alphabet letters)", "because of the historical type of spelling, conveys the sounds of Estonian in an imperfect way" (D. B. \& K. B. 1934: 721). In the third edition, there is no criticism at all (indeed, at that time Estonia was part of the USSR, so it was now a question about one of the Soviet peoples' written language): only the Roman letters of the Estonian alphabet are mentioned in this regard (Ageeva 1978). In the article from the GSE second edition, even the Estonian Roman letters are not discussed. Instead, some historical factors are 
quoted: "The first records in Estonian go back to the 13th century (several sentences and glosses). More developed texts are known from the 16th century. The first book in Estonian was published in 1535" (nomen nominandum 1957b: 226).

\section{On the history of the study of Estonian}

In the GSE first edition, we find no information about the study of Estonian in the article "Estonian Language" as such; however, it is implicitly present in the references. In particular, the following sources are mentioned here: 1) Stahl ${ }^{11}$ H[einrich], Anführung zu der estnischen Sprache, Reval 1637 "(the first grammar with a dictionary attached)"; 2) Wiedemann F[erdinand Johann], Estnischdeutsches Wörterbuch, Petersburg 1869 “(still the most complete dictionary, reedited in Saint-Petersburg in 1869 and in Tartu in 1923)"; 3) id., Grammatik der estnischen Sprache, Petersburg 1875 "(the first scientific grammar)"; 4) Kuusik T[imoteus], Vene-Eesti sõnaraamat (Russian-Estonian dictionary), Tallinn 1906, and Eesti-Vene sõnaraamat (Estonian-Russian dictionary), Tallinn 1914; 5) Kettunen L[auri Einari], Viron kielen äännehistorian pääpiirteet, Helsinki 1917 "(the principal stages of the history of the Estonian language sounds; in Finnish)"; 6) Jõgever F. [sic] [Jaan] ${ }^{12}$, Eesti keele grammatika (Grammar of the Estonian Language), r.r. I-III, Tartu 1919-20. Finally, we learn that 7) the journal Eesti keel (Estonian Language) deals with the problems of Estonian and is published in Estonia since 1922 (D. B. \& K. B. 1934: 721).

In the GSE second edition, in the references that accompany the article, in addition to the already mentioned (in the GSE first edition) books - F. Wiedemann's grammar and dictionary - we find two new sources by L. Kettunen (Kettunen L[auri Einari], Vatjan kielen äännehistoria (Phonetic history of Votian), [s.l.], 1929; id., Lauseliikmed eesti keeles (Parts of the sentence in Estonian), Tallinn 1924), as well as some books published in the USSR - both in Russian (Piall' [Päll] E[duard], Uchebnik estonskogo iazyka (Course of Estonian), Tallinn 1955; Arumaa P[eeter], Pravdin B[oris], Veski I[Johannes] V[oldemar], Russkoestonskii slovar' (Russian-Estonian dictionary), Vol. 1-10, Tartu 1940-47; these books were the first in the Bibliography), and in Estonian (Kask A[rnold], Võitlus vana ja uue kirjaviisi vahel (Fight between new and old spelling), Tartu 1946; Ariste P[aul], Eesti keele foneetika (Phonetics of the Estonian language), Tallinn 1953) (ibid.).

In the article published in the GSE third edition, the only mention about the study of Estonian in its historical aspect is that "the Estonian language was unified [unifitsirovan] in the first half of the 20th century". Even the references to this article (unlike the bibliography to the articles published in the 
GSE first and second editions) contain information reflecting, first of all, the study of Estonian at the time when this article was published. Here we find only four sources: the first two were published in Russian (Kask A[rnold], Estonskii iazyk (Estonian language), in the book: Iazyki narodov SSSR (Languages of the peoples of the USSR), Vol. 3, Moscow 1966, and Osnovy finno-ugorskogo iazykoznaniia: Pribaltiisko-finskie, saamskii i mordovskie iazyki (The foundations of Finno-Ugric linguistics: The Baltic-Finnic, Lappish and Mordvinian languages), Moscow 1975), and the last two - in Estonian, in the Estonian Soviet Socialist Republic (Ariste P[aul], Eesti keele foneetika (Phonetics of the Estonian language), 2nd ed., Tartu 1966, and Tamm J[ohan], Eesti-vene sõnaraamat (Estonian-Russian dictionary), Tallinn 1961 (Ageeva 1978). Foreign bibliographical sources are not provided in this bibliography at all, which implies mistrust in the quality of study of Estonian abroad - in contrast to its study in the USSR.

\section{The language 'as such'}

Nothing is said about the inner structure of Estonian in the article from the GSE first edition. On the contrary, the article from the second encyclopaedia edition contains the most complete (of all three GSE editions) description of the Estonian language 'as such'. As to the third edition, it seems to contain, in a contracted form, the information that has been developed in detail in the previous edition - with several exceptions, when the second and the third editions provided different linguistic data. This was the case, in particular, when the different numbers of consonant sounds in Estonian were indicated in these two $\operatorname{articles}^{13}$ or when more attention was devoted to the particular Estonian prosody in the GSE second edition (nomen nominandum 1957b: 226).

As concerns the morphology, in the GSE third edition the Estonian language is described as "inflectional-agglutinative" [flektivno-aggliutinativnyi] (Ageeva 1978): in the 1970s, linguistic typology developed in the USSR in a very dynamic way, which is reflected in the use of terminology. Meanwhile, in the GSE second edition we still find no particular terms to refer to the language types; however, we learn that in Estonian "the name formally has only one type of declination and the verb has only one type of conjugation" (nomen nominandum 1957b: 226): it would presuppose a purely agglutinative structure of the Estonian language, which is not the case.

Speaking about the Estonian vocabulary, authors of all three articles emphasise the presence of loan-words in the language. However, in this regard, articles from the second and third editions are very similar and remain factual: "In the 
Estonian language, like in all other Balto-Finnic languages, there are ancient loan-words borrowed from the Baltic, Finnic, and Slavic languages" (nomen nominandum 1957b: 226); "Estonian vocabulary includes ancient Finno-Ugric, Baltic-Finnic and properly Estonian words, together with many ancient Baltic, German, and Slavic loan-words (more recent loan-words are from German, Russian, and other languages)" (Ageeva 1978). As to the article from the GSE first edition, the presence of loan-words in Estonian is negatively connoted: in particular, we learn that "the Revel dialect" ("which is the basis of Estonian") "is more and more flooded with elements from the Finnish language" (D. B. \& K. B. 1934: 721). This affirmation would seem impossible either in the second or in the third GSE editions: they described Estonian that was already a language of one of the Soviet socialist republics.

So, as we have already stated before, the GSE first edition contained very little information about the Estonian language 'as such'. In return, the content of this article manifestly reflects some linguistic theories that dominated in the USSR in the epoch when this text was composed and that were directly connected with a whole series of extralinguistic ideological parameters.

\section{...TO IDEOLOGY REFLECTED IN LANGUAGE DESCRIPTIONS}

\section{On the 'system' versus 'family' of Finno-Ugric languages}

In the GSE second and third editions, the Estonian language is defined as to its origins: it is "the language of Estonians, which belongs to the Finno-Ugric languages"14 (nomen nominandum 1957b: 225); "the language of Estonians [...]. It belongs to the Baltic-Finnic group of Finno-Ugric (Ugro-Finnic) languages" (Ageeva 1978). As to the article from the first edition, Estonian is defined here as a language that "belongs to the Ugro-Finnic language system [author's emphasis] [...], more precisely, to its western-Finnic group" (D. B. \& K. B. 1934: 720). This statement betrays the influence of N. Marr's (1864-1934) linguistic theories upon the authors of the article: in 1923-1924, Marr gave up the very idea of the existence of language families and the notion of language families itself, replacing it with that of a stage in the language development, or with that of a system..$^{15}$ Bubrikh, one of the supposed authors of this article, was known to be under a certain influence of Marr: his many researches can be regarded as a result of an attempt to find a compromise in order to reconcile Marrism with 'traditional' comparative linguistics. Unlike Marr, Bubrikh did not completely refute the genetic relationship between languages; however, under the strong pressure of Marrists he had to make many theoretical concessions. ${ }^{16}$ 
Besides, according to Bubrikh, in the constitution of languages and peoples (including the Finno-Ugric ones), the areal factors play a considerable role. ${ }^{17}$ Likewise, in the article from the GSE first edition we find the thesis that "mass [massovyi] and extended contacts with [other] peoples - Germans, Russians, and Swedes - left deep traces in the [Estonian] language, changing not only its vocabulary, but also its morphology and phonetics. The most evident traces are those of the Baltic barons' domination" (D. B. \& K. B. 1934: 721). The last statement allows to proceed to another topic that is manifestly present in this article - the notion of class nature of a language or class distinctions in any (natural) language. This question was actively discussed in the Soviet linguistics of the $1920 \mathrm{~s}$.

\section{Estonian 'barons' language' and Estonian language of 'working and peasant population'}

In particular, the above-mentioned Baltic barons' domination and its influence on the Estonian language was supposedly connected with the fact that "with the purpose of influence over the peasant masses, it is the German pastors who had elaborated the Estonian written language. The first manuscripts in Estonian go back to the middle of the 16th century, but only in the second half of the 19th century, during the development of the literary Estonian language there was a turn towards the regulation [uporiadochenie] and towards the enrichment [obogashchenie], in connection with the fact that literature became an instrument of the Estonian national bourgeoisie that emerged at that time. A new turning-point in the development of the Estonian literary language can be connected with the emergence of the Estonian bourgeois republic, when literature became an instrument of the dominating class. i.e. the bourgeoisie. Now the Estonian language is elaborated without any connection with the demands of working and peasant masses; for a moment, the northern (Revel) dialect has been finally $[s i c]$ established as its basis, at the same time it is more and more flooded with the Finnish language elements. In connection with this, in the Estonian circles of the USSR, the idea about the creation of an Estonian literary language, which would be close to the language of working and peasant masses, grows stronger and stronger" (D. B. \& K. B. 1934: 721).

In the Soviet Union of the 1920s-1930s, the idea of class distinctions in the language runs all through the works of both obvious Marrists and linguists who did not unambiguously belong to the Marrist paradigm; sometimes even the existence of national languages as such was denied (for instance, in G. K. Danilov's works (1929a, 1929b)). From time to time, Marr himself also refuted the exist- 
ence of 'national languages' (cf. Marr 1933-1937, II: 415), maintaining that only 'class languages' exist and that, for instance, languages of representatives of the same class in various countries are more similar than the languages of different classes of the same people (ibid.). However such statements did not prevent Marr from writing about the Estonian, Russian, and other 'national languages', which shows to what extent Marr's theories were contradictory. The division of language into 'class languages', without the denial of the very idea of the 'national language', is de facto also presupposed in the article about Estonian published in the GSE first edition.

\section{CONCLUSION}

As we can see, even the seemingly neutral articles about the Estonian language published in the GSE are ideologically charged, reflecting the particular political and social situation of the epochs when they were composed. It can be seen both in the references accompanying the articles (Soviet of foreign sources quoted) and in particular fragments of the language description (are loanwords or the written language as such criticised, or the attitude towards them is neutral, etc.). In this regard, the article from the GSE first edition is the least neutral: it reflects the influence of Marrism on its authors; the language 'as such' is described very little, while the extralinguistic situation around Estonian is presented rather negatively. It can be explained by the fact that, in the early 1930s, Estonia was not yet a part of the USSR, which made it possible to criticise the 'non-Soviet' Estonian language, its dependence on the dominating class of the bourgeoisie, the flood of Finnish elements in Estonian, etc. In addition to a particular (scientific) ideology, all this reflects the style and language of the Soviet linguistics itself during the same epoch.

\section{ACKNOWLEDGEMENT}

I would like to thank Prof. Kalevi Kull for his helpful and critical comments. 


\section{NOTES}

1 To Prof. Urmas Sutrop on the occasion of his 60th birthday, with much gratitude for his work.

2 The question about the 'impartiality' in language descriptions presents a particular problem first of all in connection with the opposition 'ontological versus constructed (object of study)'.

3 By ideology we mean here an aggregate of doctrines, opinions or beliefs shared by members of a group.

${ }^{4}$ In the GSE first edition, there were 65 volumes and the additional volume titled The USSR, which had no number.

5 The GSE second edition contained 49 volumes, the 50th volume titled The USSR, the additional 51st volume and the volume 52, Alphabetical Index, edited in two books (1960).

6 One of the thirty volumes of the GSE third edition was published in two books (the additional book under the title The USSR), to which was added the volume Alphabetical Index of Names (which had no number).

7 Taking into account the limited volume of this article, I am not going to discuss all fragments of the Estonian language descriptions presented in the GSE, but only those that seem particularly important within the framework of my general subject, "Linguistics and ideology".

8 Cf. in this regard the following quotation: "A new epoch [etap] for the Estonians began after the restoration of the Soviet power in 1940. In the process of socialist construction, in the political, economic, and cultural collaboration with other peoples of the USSR, the Estonian nation has transformed into a socialist one" (Viires 1978).

9 For instance, in the article titled "Estonians" and published in the GSE third edition, we read the following: "Estonians, a nation (in the second edition, 'socialist nation' (nomen nominandum 1957a)), basic population of the Estonian Soviet Socialist Republic" (Viires 1978). Cf. in this connection the definition of the Estonian language from the Concise Literary Encyclopaedia, also published in the USSR: "Estonian language is the language of Estonians, the basic population of the Estonian Soviet Socialist Republic" (Kask \& Ageeva 1975: 978).

${ }^{10}$ Here the region of spread of Estonian coincides exactly with the one where the Estonians live, according to the article "Estonians" published in the same GSE edition: "Estonia, Russian Soviet Federative Socialist Republic (Leningrad; Leningrad, Pskov, and Omsk oblasts, etc.), Latvian Soviet Socialist Republic, Ukrainian Soviet Socialist Republic, Abkhaz Autonomous Soviet Socialist Republic, USA, Sweden, Canada" (Viires 1978) (in this way the sign of equality between language and the corresponding people was implicitly presupposed).

${ }^{11}$ Hereinafter I have added full names to the GSE spelling. The spelling of titles of all quoted sources corresponds to the GSE one. Source titles are italicised by the editor; additional bibliographical data and translations of the titles are also sometimes provided by the editor. 
${ }^{12}$ Wrong first name in the GSE (E.V.).

${ }^{13}$ Precisely 'sounds', and not 'phonemes' were under discussion in these articles, even if at present the word phoneme would seem more appropriate in this context.

${ }^{14}$ Besides, unlike the GSE first and third editions, the second edition mentions the "nearest relations" of Estonian: they are Livonian and Votic languages (nomen nominandum 1957b: 225).

15 With particular regard to the Estonian language, I analyse Marr's theories in the article Estonskii iazyk glazami sozdatelia "novogo ucheniia o iazyke” (Vel'mezova forthcoming).

${ }^{16} \mathrm{Cf}$., for example, in his Autobiography: "[...] with my bourgeois education, I could not immediately get free from the methodology of bourgeois linguistics in order to appreciate properly academician N. Marr's Japhetic theory [in this particular context, Japhetic theory is the same as Marrism] developing towards the Marxist-Leninist linguistics. Having accepted a series of Japhetic theory theses (for instance, those against the idea of protolanguages), I had harshly argued against others, for instance, against those that were based on the idea of the discovery of sound speech primary elements. Nevertheless, I should say that already by 1932, I had found the right line" (Bubrikh 1934). And the following is the description of Bubrikh's situation in the early 1930s by V. M. Alpatov: “[...] Bubrikh has also surrendered. And N. Troubetzkoy, who had once found in one of his works the 'signs of genius', was disappointed in Bubrikh's work about the Erzya-Mordvinian language [(...) 1935 (...)], where he refuted the principles of comparative linguistics" (Alpatov 1991: 93, cf. also 118, 128-129, 140, 199). Despite his many attempts to find theoretical compromises with Marrists, in spite of the fact that in 1934-1949 Bubrikh was in charge of the Finno-Ugric department at the N. Ia. Marr Institute of Language and Thought, he suffered much because of the Marrists - both because of their criticism in the early 1930s (ibid.: 101) and because of their persecutions in the late 1940s, which finally cost Bubrikh his life (ibid.: 158-159).

${ }^{17}$ Later it was emphasised, in particular, in the article of Bubrikh's disciple Georgii Martynovich Kert (1923-2009) on the example of Bubrikh's study of the Karelians' origin (Kert 2002; cf. also Alpatov 1991: 133, etc.). 


\section{REFERENCES}

Ageeva, Ruf' 1978. Estonskii iazyk. [The Estonian Language.] In: Aleksandr Prokhorov (chief ed.) Bol'shaia sovetskaia entsiklopediia. 3rd edition, Vol. 30. Moscow: Sovetskaia entsiklopediia, p. 284.

Alpatov, Vladimir 1991. Istoriia odnogo mifa: Marr i marrizm. [The History of a Myth: Marr and Marrism.] Moscow: Nauka, Glavnaia redaktsiia vostochnoi literatury.

Bubrikh, Dmitrii 1934. Zhizneopisanie Dmitriia Vladimirovicha Bubrikha. [Dmitrii Vladimirovich Bubrikh's Biography.] Available at http://iling.spb.ru/pdf/liudi/ bubrih.html, last accessed on May 17, 2016.

D. B. \& K. B. 1934. Estonskii iazyk. [The Estonian Language.] In: Otto Shmidt (chief ed.) Bol'shaia sovetskaia entsiklopediia. 1st edition, Vol. 64. Moscow: OGIZ RSFSR, Gosudarstvennoe slovarno-entsiklopedicheskoe izdatel'stvo Sovetskaia entsiklopediia, pp. 720-721.

Danilov, Georgii 1929a. Iazyk obshchestvennogo klassa. [The Language of a Social Class.] Uchenye zapiski Instituta iazyka i literatury RANION, Vol. 3, pp. 163-194. Available at http://crecleco.seriot.ch/textes/DANILOV29/txt.html, last accessed on May 17, 2016.

Danilov, Georgii 1929b. Marksistskii metod v leksikologii. [The Marxist Method in Lexicology.] Russkii iazyk v sovetskoi shkole, No. 6, pp. 48-62. Available at http:// crecleco.seriot.ch/textes/Danilov29b.html, last accessed on May 17, 2016.

Kask, Arnol'd \& Ageeva, Ruf' 1975. Estonskii iazyk. [The Estonian Language.] In: Aleksei Surkov (chief ed.) Kratkaia literaturnaia entsiklopediia, Vol. 8. Moscow: Izdatel'stvo Sovetskaia entsiklopediia, pp. 978-979. Available at http://feb-web. $\mathrm{ru} / \mathrm{feb} / \mathrm{kle} / \mathrm{kle}$-abc/default.asp, last accessed on May 17, 2016.

Kert, Georgii 2002. Velichie i tragediia talanta. [The Grandeur and Tragedy of a Talent.] In: G. Kert Ocherki po karel'skomu iazyku: Issledovaniia i razmyshleniia. 2nd edition. Petrozavodsk: Kareliia, pp. 83-107. Available at http://www.voinitsa. ru/pages/art243.aspx, last accessed on May 17, 2016.

Marr, Nikolai 1933-1937. Izbrannye raboty. [Selected Works.] Vol. I-V. Moscow \& Leningrad: Izdatel'stvo gosudarstvennoi akademii istorii material'noi kul'tury (Vol. I), Gosudarstvennoe sotsial'no-ekonomicheskoe izdatel'stvo (Vol. II-V).

Nomen nominandum 1957a. Estontsy. [The Estonians.] In: Boris Vvedenskii (chief ed.) Bol'shaia sovetskaia entsiklopediia. 2nd edition, Vol. 49. Moscow: Gosudarstvennoe nauchnoe izdatel'stvo Bol'shaia sovetskaia entsiklopediia, pp. 226-228.

Nomen nominandum 1957b. Estonskii iazyk. [The Estonian Language.] In: Boris Vvedenskii (chief ed.) Bol'shaia sovetskaia entsiklopediia. 2nd edition, Vol. 49. Gosudarstvennoe nauchnoe izdatel'stvo Bol'shaia sovetskaia entsiklopediia, pp. 225-226.

Vel'mezova, Ekaterina forthcoming. Estonskii iazyk glazami sozdatelia "novogo ucheniia o iazyke". [The Estonian Language as Viewed by the Creator of the "New Theory of Language”.] In: Anastasiia de Lia Fortel' \& Sebast'ian More (chief eds.) Sbornik statei $k$ 65-letiiu Patrika Serio. Moscow: OGI. 
Viires, Ants 1978. Estontsy. [The Estonians.] In: Aleksandr Prokhorov (chief ed.) Bol'shaia sovetskaia entsiklopediia. 3rd edition, Vol. 30. Moscow: Sovetskaia entsiklopediia, p. 284. 